\title{
PRAWO DO WYPOCZYNKU OSÓB PRACUJĄCYCH NA WLASNY RACHUNEK - UWAGI DE LEGE FERENDA
}

\begin{abstract}
Streszczenie. Przedmiotem niniejszego opracowania jest kwestia związana z prawem do wypoczynku osób samozatrudnionych. Obecne przepisy Konstytucji RP z 2.04.1997 r. w tej materii nie są jednoznaczne i należałoby dokonać ich rewizji. Po pierwsze, nie są zgodne z aktami prawa międzynarodowego. Po drugie, nie odzwierciedlają obecnych realiów społeczno-gospodarczych. Zdaniem autora, zakres podmiotowy prawa do wypoczynku powinien być rozszerzony na osoby samozatrudnione, które spełniają - określone w opracowaniu - kryteria.
\end{abstract}

Słowa kluczowe: samozatrudnienie, praca na własny rachunek, prawo do wypoczynku.

\section{GENEZA I EWOLUCJA PRAWA DO WYPOCZYNKU}

Prawo do wypoczynku jest jednym z najważniejszych uprawnień, jakie przysługuje człowiekowi wykonującemu pracę. Już w XIX wieku stało się ono głównym postulatem wielu ruchów robotniczych, co wskazywało - w tamtym czasie - na ogromną potrzebę ograniczenia wymiaru czasu pracy. Konieczność zapewnienia odpowiedniego wypoczynku dostrzegł także papież Leon XIII, który pod koniec XIX wieku wydał encyklikę Rerum novarum. Zawarto w niej wiele postulatów dotyczących ochrony ludzi pracy, zwłaszcza w kontekście polepszenia warunków ich pracy. Jednym z najważniejszych był dezyderat dotyczący prawa do wypoczynku. Papież Leon XIII wskazał, że odpoczynek jest bardzo istotny i powinien wynosić tyle, ile potrzeba na pełną regenerację sił. Do podobnych wniosków doszedł, prawie sto lat później, papież Jan Paweł II, który w encyklice Laborem exercens uznał, iż praca ma nie tylko charakter przedmiotowy, ale przede wszystkim podmiotowy. W cytowanej encyklice szeroko postulował prawo do wypoczynku. Wskazywał, iż stanowi ono ważny element odpowiednich warunków pracy. Głos Kościoła katolickiego odegrał niebagatelną rolę w zakresie praw pracowniczych, zwłaszcza w kwestii prawa do wypoczynku. Wiele postulatów, w tym dotyczących ograniczenia czasu pracy, znalazło swoje odzwierciedlenie w międzynarodowych i krajowych regulacjach prawnych.

*Uniwersytet Łódzki, Wydział Prawa i Administracji, Katedra Prawa Pracy, mbarwasny@, wpia.uni.lodz.pl 
Pierwszym aktem międzynarodowym, który odnosił się do tej kwestii, była Konwencja Nr 1 Międzynarodowej Organizacji Pracy (dalej: MOP) z dnia 29 października 1919 r. dotycząca ograniczenia czasu pracy do 8 godzin dziennie i 48 godzin tygodniowo w zakładach przemysłowych (http://www.mop.pl/doc/ $\mathrm{html} /$ konwencje/k001.html). Wprowadziła ona ograniczenia w zakresie czasu pracy, na jej podstawie skrócono go do 8 godzin dziennie i 48 godzin tygodniowo w zakładach przemysłowych. Warto podkreślić, że w celu prawidłowego stosowania cytowanej Konwencji wprowadzono dla pracodawców obligatoryjny obowiązek umieszczania w widocznym miejscu informacji o godzinach rozpoczęcia i zakończenia czasu pracy. Należy podkreślić, że wyżej wspomniana Konwencja rozpoczęła międzynarodową dyskusję na temat regulacji ochronnych dotyczących prawa do odpoczynku. Na jej kanwie, w późniejszych latach, powstało kilka aktów, które stopniowo rozszerzały tę ochronę na inne podmioty. Warto tu wspomnieć m.in. o: Konwencji Nr 14 MOP z 17 listopada 1921 r. o odpoczynku tygodniowym w zakładach przemysłowych (Dz.U. z 1925 r. Nr 54, poz. 384); Konwencji $\mathrm{Nr} 106$ z 5 czerwca 1957 r. o cotygodniowym odpoczynku w handlu i biurach (http://www.mop.pl/doc/html/konwencje/k106.html); Konwencji Nr 30 z 28 czerwca 1930 r. dotyczącej uregulowania czasu pracy w handlu i w biurach (http:// www.mop.pl/doc/html/konwencje/k030.html) oraz Konwencji Nr 47 z 22 czerwca 1935 r. dotyczącej skracania czasu pracy do 40 godzin tygodniowo (http://www. mop.pl/doc/html/konwencje/k047.html).

Także w aktach Organizacji Narodów Zjednoczonych (dalej: ONZ) dostrzeżono potrzebę ochronę w zakresie czasu pracy i prawa do wypoczynku. Widać to choćby w uchwalonej 10 grudnia 1948 r. w Paryżu przez Zgromadzenie Ogólne ONZ Powszechnej Deklaracji Praw Człowieka (dalej: PoDePrCzł). Art. 24 tego aktu wprowadza wymóg zagwarantowania każdemu człowiekowi prawa do urlopu i wypoczynku, włączając w to rozsądne ograniczenie godzin pracy i okresowe płatne urlopy. Konkretyzacja i rozszerzenie katalogu uprawnień zawartych w Powszechnej Deklaracji Praw Człowieka nastąpiły w grudniu 1966 r., kiedy to Zgromadzenie Ogólne ONZ uchwaliło Międzynarodowy Pakt Praw Gospodarczych, Społecznych i Kulturalnych (dalej: MPPGSK). Warto podkreślić, iż w przeciwieństwie do PoDePrCzł, Pakt ten ma charakter wiążący, ponieważ jest umową międzynarodową i obowiązuje wszystkie kraje, które go ratyfikowały. Z punktu widzenia ochrony w zakresie wypoczynku istotny jest art. 7 MPPGSK dotyczący prawa do sprawiedliwych i korzystnych warunków pracy, które przysługują każdej istocie ludzkiej. Uprawnienie to obejmuje uzyskiwanie przez pracujących godziwego i równego wynagrodzenia za pracę o równej wartości bez jakiejkolwiek różnicy, a także zrównanie warunków pracy i płacy kobiet i mężczyzn. Elementem tego prawa jest także zapewnienie pracującym bezpiecznych i higienicznych warunków pracy oraz odpowiedniego wypoczynku, czasu wolnego i rozsądnego ograniczenia czasu pracy, okresowych płatnych urlopów oraz wynagrodzenia za dni świąteczne. Analizując przepisy Powszechnej Deklaracji Praw Człowieka 
oraz Międzynarodowego Paktu Praw Gospodarczych, Społecznych i Kulturalnych warto podkreślić, że przyznają one uprawnienia, także te z zakresu sfery społeczno-ekonomicznej, każdemu człowiekowi. Taka konstrukcja sprawia, że nie uzależniają one tej ochrony od jakichkolwiek innych przymiotów. Wynika z tego, że prawo do wypoczynku powinno przysługiwać wszystkim, bez względu na formę świadczenia pracy. W moim przekonaniu beneficjentami praw społeczno-ekonomicznych, które zostały określone w Deklaracji oraz MPPGSK, nie są jedynie osoby zatrudnione na podstawie stosunku pracy, ale także pracujące (świadczące pracę lub usługi) w ramach umów cywilnoprawnych i samozatrudnienia, a nawet osoby świadczące pracę bez wyraźnej podstawy prawnej (tzw. szara strefa). Twórcy tych aktów, przyznając poszczególne prawa, kierowali się ochroną wartości życia ludzkiego oraz innych ważnych obszarów, które związane są z działalnością człowieka. Do takiej sfery zakwalifikowano pracę człowieka, która ma wymiar nie tylko ekonomiczny, ale także społeczny, dlatego też podmioty, które ją wykonują, powinny być objęte odpowiednią ochroną prawną, także w zakresie prawa do wypoczynku.

Kolejnym uniwersalnym międzynarodowym aktem prawnym, w którym znajdują się gwarancje dotyczące prawa do wypoczynku, jest - obowiązująca od 1965 r. - Europejska Karta Społeczna (Europejska Karta Społeczna z dnia 18 października 1961 r., Dz.U. z 1999 r. Nr 8, poz. 67). Artykuł 2 tego aktu, regulujący prawo do odpowiednich warunków pracy, zobowiązuje państwa do określenia rozsądnego dziennego i tygodniowego czasu pracy, a także do jego skrócenia w przypadku wzrostu wydajności, zapewnienia płatnych dni świątecznych, corocznego, co najmniej dwutygodniowego płatnego urlopu oraz tygodniowego odpoczynku.

Akty prawa międzynarodowego niewątpliwie wpisują prawo do wypoczynku wykonawców pracy w poczet praw człowieka, co świadczy o jego wysokiej pozycji wśród innych uprawnień. Warto także podkreślić, że używanie zwrotu „każdy” wskazuje, iż nie dotyczy ono wyłącznie pracowników, lecz jest kierowane do wszystkich, którzy świadczą pracę, bez względu na więź prawną łączącą ich $\mathrm{z}$ podmiotem zatrudniającym. Jest to bardzo istotne, ponieważ nie ma wątpliwości co do tego, że ideą wprowadzenia prawa do wypoczynku była ochrona osób świadczących pracę przed niekorzystnymi warunkami pracy polegającymi na zbyt dużej eksploatacji ludzkiego organizmu.

Problem w zakresie odpowiedniego wypoczynku mają przede wszystkim osoby samozatrudnione. Jak pokazują badania przeprowadzone przez Główny Urząd Statystyczny, aż 76,5\% pracujących na własny rachunek przepracowało w badanym tygodniu 40 godzin i więcej (GUS, Aktywność ekonomiczna ludności Polski 2017, BAEL, http://stat.gov.pl/obszary-tematyczne/rynek-pracy/pracujacy-bezrobotni-bierni-zawodowo-wgbael/aktywnoscekonomiczna-ludnosci-polski-ii-kwartal-2017-roku,4,25.html, s. 143). Statystyki te wskazują, że ponad 3/4 samozatrudnionych pracuje dłużej niż osoba zatrudniona na pełnym etacie $\mathrm{w}$ ramach 
stosunku pracy. Powstaje zatem pytanie, czy osoby samozatrudnione, zwłaszcza zależne ekonomicznie, mają prawo do wypoczynku. A jeśli nie, to jakie rozwiązania prawne należy przyjać, aby zagwarantować realizację tego uprawnienia. Nie ulega wątpliwości, iż właściwy odpoczynek jest bardzo ważny nie tylko z punktu widzenia osoby świadczącej pracę, lecz także z perspektywy interesu podmiotu zatrudniającego.

\section{PRAWO DO WYPOCZYNKU W ŚWIETLE KONSTYTUCJI RP}

Konstytucja RP z 2 kwietnia 1997 r. (Dz.U. z 1997 r. Nr 78, poz. 483), na wzór innych państw i instytucji międzynarodowych, również gwarantuje prawo każdego człowieka do wypoczynku. Ustawa zasadnicza umiejscawia prawo do odpoczynku wśród wolności i praw ekonomicznych, socjalnych i kulturalnych, co pozwala je zakwalifikować do konstytucyjnych praw człowieka. Dla problematyki związanej z prawem do wypoczynku istotny jest art. 66 Konstytucji RP, który w swojej treści przyznaje dwa zasadnicze uprawnienia. Pierwszym z nich jest prawo każdego do bezpiecznych i higienicznych warunków pracy. Od razu należy tutaj zwrócić uwagę na zwrot „każdy”, który wskazuje na to, że ustrojodawca w bardzo szerokim zakresie zakreślił krąg podmiotów posiadających to uprawnienie. Nie ulega wątpliwości, że osoby świadczące pracę są szczególnie narażone na utratę zdrowia, a nawet życia. Dlatego też prawodawca konstytucyjny zdecydował się nadać to prawo każdemu człowiekowi, nawet temu, który świadczy swoją pracę bez wyraźnej podstawy prawnej. Doktryna wskazuje na kilka interpretacji sformułowania „każdy” użytego w art. 66 ust. 1 Konstytucji RP. Według najwęższego rozumienia, sformułowanego przez W. Sanetrę, powyższy przepis odnosi się jedynie do zatrudnienia pracowniczego (Sanetra 1997, 2). W mojej opinii powyższy pogląd nie zasługuje na aprobatę, ponieważ jego autor stosuje wykładnię zawężającą, co w kontekście katalogu praw człowieka wydaje się niewłaściwe. $\mathrm{W}$ związku z tym należy przyjąć, iż beneficjentami normy z art. 66 ust. 1 Konstytucji RP są wszystkie osoby świadczące pracę, także te zatrudnione w ramach umów cywilnoprawnych oraz samozatrudnienia.

Drugim uprawnieniem wynikającym z art. 66 Konstytucji RP jest prawo do wypoczynku. Warto zaznaczyć, że ustawa zasadnicza w art. 66 ust. 2 nie używa wprost określenia ,prawo do wypoczynku”, lecz wymienia elementy składowe tego prawa, takie jak: prawo do określonych w ustawie dni wolnych od pracy i corocznych płatnych urlopów oraz zobowiązanie dla ustawodawcy do określenia maksymalnych norm czasu pracy. Natomiast określenie „prawo do wypoczynku” zostało wprost użyte w art. 233 ust. 3 Konstytucji RP, który przyznaje możliwość ograniczenia wymienionych praw, w tym prawa do wypoczynku, w przypadku wystąpienia stanu klęski żywiołowej. 
Prawodawca konstytucyjny w art. 66 ust. 2 Konstytucji RP, określając zakres podmiotowy normy, posłużył się określeniem ,pracownik”, co z punktu widzenia ochrony prawnej ma bardzo istotne znaczenie. Biorąc pod uwagę wykładnię literalną, należy przyjąć, iż prawo do wypoczynku gwarantuje się jedynie osobom pozostającym w stosunku pracy (Banaszak, Jabłoński 1998, 124). Ponadto należy zauważyć, że - zgodnie z zasadą racjonalnego ustrojodawcy - twórcy Konstytucji RP świadomie zawęzili krąg podmiotów uprawnionych do prawa do wypoczynku, opierając się na art. 2 Kodeksu pracy (Ustawa z dnia 26 czerwca 1974 r. - Kodeks pracy, Dz.U. z 2016 r., poz. 1666). W związku z tym, zgodnie z poglądem wyrażonym przez T. Liszcz, należy rozróżnić sformułowania użyte w art. 66 Konstytucji RP, choćby ze względu na wykładnię literalną przepisów (Liszcz 2009, 180).

Stwierdzając, że zwroty występujące w art. 66 Konstytucji RP, tj. „każdy” (ust. 1) i „pracownik” (ust. 2) powinno się wyraźnie rozróżnić, należy określić, co oznacza termin ,pracownik” na gruncie przepisów prawa. Definicja legalna pracownika znajduje się w Kodeksie pracy, gdzie art. 2 stanowi, iż „pracownikiem jest osoba zatrudniona na podstawie umowy o pracę, powołania, wyboru, mianowania lub spółdzielczej umowy o pracę". Z tego wynika, że na kanwie przepisów prawa pracy - pracownikiem jest jedynie osoba zatrudniona na wyżej wskazanych podstawach prawnych. Pracownikiem nie jest zatem osoba zatrudniona w ramach umowy cywilnoprawnej czy samozatrudnienia. Powstaje pytanie, czy sformułowane w art. 66 ust. 2 określenie ,pracownik” jest tożsame z definicją legalną pracownika, znajdującą się w art. 2 k.p., czy może termin ten należy także stosować do osób niepozostających w stosunku pracy, w tym do samozatrudnionych. Warto podkreślić, iż Trybunał Konstytucyjny wskazuje na autonomię terminów konstytucyjnych, która oznacza, iż te same pojęcia znajdujące się w Konstytucji i ustawach zwykłych mogą posiadać różne znaczenia (Wiącek-Burmańczuk 2017, 111). Zgodnie z wyrokiem TK z 2.12.2008 r., nie powinno się interpretować pojęć użytych w przepisach konstytucyjnych przez pryzmat ich odpowiedników zawartych w ustawach zwykłych (K37/07, OTK ZU 2008/10A/172). W tym miejscu warto także wskazać na wyrok TK z 13.05.2009 r. (Kp2/09, OTK ZU 2009/5A/66), zgodnie z którym - pomimo autonomiczności pojęć konstytucyjnych - odwołanie się do znaczenia terminów określonych w ustawach zwykłych nie jest błędem. Z kolei w wyroku z dnia 2.06.2015 r. (K 1/13, Dz.U. z 2015 r., poz. 791) TK zdefiniował konstytucyjne rozumienie pojęcia ,pracownik” w kontekście zakresu podmiotowego prawa koalicji. Uznał, że pracownikiem jest osoba, która - po pierwsze - wykonuje określoną pracę zarobkową, po drugie - pozostaje w stosunku prawnym z podmiotem, na rzecz którego ją świadczy, po trzecie zaś - ma takie interesy zawodowe związane z wykonywaniem pracy, które mogą być grupowo chronione. Koncepcja ta została krytycznie oceniona przez A. M. Świątkowskiego, który stwierdził, że TK bez żadnej podstawy prawnej skonstruował alternatywną, w stosunku do definicji sformułowanej w art. 2 k.p., definicję legalną pracownika (Świątkowski 2016, s. 8 i n.). A. M. Świątkowski 
uznał, iż nie ma potrzeby tworzenia odrębnej definicji pracownika na gruncie Konstytucji, gdyż jest ona jedna i została zawarta w przepisach Kodeksu pracy. Moim zdaniem, należy zgodzić się z twierdzeniem, iż w jednym systemie prawa nie mogą funkcjonować dwie równorzędne definicje pracownika, ponieważ prowadzi to do chaosu prawnego. Warto tutaj także wskazać na to, że nie ma żadnych podstaw prawnych do wyodrębnienia dwóch kategorii pracowników: sensu largo i sensu stricto. W związku z powyższym można dojść do wniosku, że dla określenia pojęć konstytucyjnych należy raczej stosować definicje legalne zawarte w ustawach zwykłych, niż tworzyć dodatkowe, alternatywne definicje na potrzeby interpretacji przepisów konstytucyjnych.

Interpretacją terminu ,pracownik” zajął się także SN w uchwale z 15.12.2005 r. (I KZP 34/05, OSP 2006, nr 7-8, poz. 93). Dotyczyła ona ustalenia znaczenia tego pojęcia w świetle art. 220 Kodeksu karnego (Ustawa z dnia 6 czerwca 1997 r. - Kodeks karny, Dz.U. z 2016 r., poz. 1137). Warto zwrócić uwagę, że k.k. nie zawiera definicji pracownika, dlatego też istniał problem z określeniem zakresu podmiotowego stosowania tego przepisu. SN w sprawie tej uznał, że termin „pracownik” sformułowany w cytowanym przepisie odnosi się jedynie do osoby pozostającej w stosunku pracy na gruncie k.p. Warto podkreślić, że SN przyznał, iż „pracownik" nie oznacza jedynie osoby zatrudnionej na podstawie umowy o pracę, powołania, wyboru, mianowania lub spółdzielczej umowy o pracę, ale należy także brać pod uwagę art. $22 \S 1$ i $1^{1}$ k.p., co rozciąga to znaczenie również na osoby, które formalnie nie są zatrudnione na wyżej wymienionych podstawach prawnych, lecz w rzeczywistości świadczą pracę w ramach stosunku pracy. Stanowisko zaprezentowane przez SN w tej uchwale wywołało niejednoznaczne opinie wśród przedstawicieli doktryny. $Z$ jednej strony krytykowano uchwałę za przyjęcie zbyt wąskiego rozumienia terminu „pracownik” (Jankowiak, Musiała 2007, 163-167), z drugiej zaś uznawano, iż prezentuje ona najbardziej wyważony pogląd (Daniluk, Witoszko 2006).

W tym miejscu warto wskazać na pogląd wyrażony przez A. Sobczyka, który uznał, iż nie powinno się ograniczać konstytucyjnego pojęcia „pracownik” wyłącznie do osób pozostających w stosunku pracy. Stwierdził, że termin ten oznacza osobę, która wykonuje pracę zarobkową w zakładzie pracy lub w innym miejscu. Ponadto uznał, iż dla rozumienia pojęcia „pracownik” nie mają znaczenia podporządkowanie pracodawcy lub jego brak oraz podstawa zatrudnienia (Sobczyk 2013, 195). Do podobnych wniosków doszedł B. Banaszak, który stwierdził, że na gruncie art. 66 ust. 2 Konstytucji RP pracownik powinien być rozumiany tak samo szeroko jak w art. 66 ust. 1, ponieważ nie ma powodów, aby różnicować zakres podmiotowy obu tych przepisów (Banaszak 2009, 345). Powstaje zatem pytanie, dlaczego ustawodawca uregulował te przepisy w taki sposób, że - zgodnie z wykładnią literalną - mamy do czynienia z dwoma różnymi zakresami podmiotowymi? Trudno jednoznacznie odpowiedzieć na to pytanie, jednak - moim 
zdaniem - zakładając racjonalność naszego prawodawcy, nie można przyjąć tożsamości podmiotowej obu analizowanych unormowań.

Nie bez znaczenia dla przyjęcia właściwej interpretacji pojęcia „pracownik” w normach konstytucyjnych jest również termin ,praca” oraz zasada ochrony pracy, która została sformułowana w art. 24 Konstytucji RP. TK w wyroku z dnia 23.02.2010 r. (P 20/09, Dz.U. Nr 34, poz. 191) uznał, że pojęcie to oznacza wszelką pracę zarobkową na rzecz innego podmiotu bez względu na formalne zakwalifikowanie stosunku łączącego te podmioty. Ponadto, według A. Wiącek-Burmańczuk (Wiącek-Burmańczuk 2017, 113), normę wyrażoną w art. 66 ust. 2 Konstytucji RP należy interpretować jako rozwinięcie, sformułowanej w art. 24 Konstytucji RP, zasady ochrony pracy. Gwarantuje ona poszanowanie każdej pracy, zapewnia trwałość zatrudnienia, pracę w bezpiecznych i higienicznych warunkach, a także wprowadza ochronę świadczeń związanych z pracą oraz zapobiega bezrobociu (Dral, Bury 2014, 237). Zgodnie z wyrokiem SN z dnia 7.10.2004 r. (II PK 29/04), art. 24 Konstytucji RP zawiera deklarację, w myśl której państwo obejmuje ochroną warunki, zakres i treść świadczenia pracy, która odbywa się w obrębie stosunków cywilnoprawnych oraz innego rodzaju zatrudnienia. Na tej podstawie można dojść do wniosku, że termin ,pracownik" użyty w art. 66 ust. 2 Konstytucji RP powinien dotyczyć nie tylko zatrudnionych $\mathrm{w}$ ramach stosunku pracy (określonego w Kodeksie pracy), ale także innych osób, które wykonują osobiście pracę zarobkową, w tym również pracujących na własny rachunek.

Konstytucja RP w art. 66 ust. 1 gwarantuje każdemu prawo do bezpiecznych i higienicznych warunków pracy. Treść tego uprawnienia nie została skonkretyzowana w Konstytucji, jednakże możemy przyjąć, iż oznacza ono to, że „każdy powinien mieć zagwarantowane takie warunki pracy, które nie zagrażają jego życiu i zdrowiu” (Lewandowski 2009, 16). Warto zwrócić uwagę, że pojęcie „warunki pracy" należy interpretować szeroko, ponieważ odnosi się ono zarówno do kwestii natury technicznej, jak i organizacyjnej, na którą składają się m.in. regulacje dotyczące czasu pracy oraz prawa do wypoczynku (Sobczyk 2013, 185). Tak jak wcześniej wspomniałem, Konstytucja RP nie definiuje terminu „,bezpieczne i higieniczne warunki pracy", dlatego też w literaturze przedmiotu wskazuje się na jego elementy składowe. Są nimi zarówno odpowiednie ukształtowanie organizacji czasu pracy, jak również gwarancja prawa do wypoczynku. Okazuje się bowiem, że zbyt długi czas pracy oraz brak urlopu wypoczynkowego mają niekorzystny wpływ na zdrowie fizyczne i psychiczne każdego wykonawcy pracy, a nawet zagrażają jego życiu (Garlicki, Zubik 2016, art. 66). W związku z powyższym można dojść do wniosku, że konstytucyjna ochrona prawa do bezpiecznych i higienicznych warunków pracy, skonstruowana w art. 66 ust. 1 Konstytucji RP, odnosi się także do prawa do wypoczynku. Na jego podstawie - moim zdaniem - można wnioskować, że uprawnienie to niejako wpisuje się w konstytucyjną ochronę w zakresie bhp, dlatego też powinno przysługiwać każdej osobie świadczącej pracę. 
Przepisy Konstytucji RP dotyczące zakresu podmiotowego prawa do wypoczynku są niejednoznaczne, co powoduje wiele problemów związanych z rozciągnięciem tego uprawnienia na osoby świadczące pracę na innych podstawach niż stosunek pracy. Konstytucja RP, uchwalona ponad 20 lat temu - w moim przekonaniu - nie odzwierciedla obecnych realiów społeczno-gospodarczych, zwłaszcza w kwestii dynamicznie zmieniającego się rynku pracy. Wyjściem z tej sytuacji jest zmiana treści art. 66 ust. 2 Konstytucji RP, której można dokonać w dwojaki sposób. Po pierwsze, poprzez zastąpienie zwrotu „pracownik” wyrazem „każdy”. Po drugie, poprzez zostawienie obecnego brzmienia przepisu z jednoczesnym wprowadzeniem definicji pracownika, która rozszerzałaby ochronę także na osoby świadczące pracę w ramach umów cywilnoprawnych i samozatrudnienia. Powyższe rozwiązania byłyby zgodne $\mathrm{z}$ aktami prawa międzynarodowego, które w tym zakresie rozciągają ochronę prawną na każdego człowieka, a nie tylko na osoby zatrudnione w ramach stosunku pracy.

\section{KRYTERIA PODMIOTOWE PRAWA DO WYPOCZYNKU DLA OSÓB PRACUJĄCYCH NA WLASNY RACHUNEK - UWAGI DE LEGE FERENDA}

Postulując rozszerzenie zakresu podmiotowego prawa do wypoczynku, zwłaszcza w kontekście wprowadzenia płatnych urlopów oraz maksymalnych norm czasu pracy, na osoby pracujące na własny rachunek, należy zastanowić się, czy wszystkim samozatrudnionym powinna przysługiwać ochrona prawna $\mathrm{w}$ tym przedmiocie.

Na gruncie polskiego prawa pracy nie istnieje legalna definicja samozatrudnienia, co rodzi szereg problemów interpretacyjnych. Należy jednak przyjąć, iż chodzi o taki rodzaj aktywności, w ramach której osoba prowadząca daną działalność, z prawnego punktu widzenia, ponosi wszelkie konsekwencje majątkowe oraz ryzyko gospodarcze związane z realizacją tejże działalności, odpowiadając za jej efekty całym swoim majątkiem (Szanciło 2005, 8-9). Przez osobę fizyczną wykonującą działalność gospodarczą, która jest przyjmującym zlecenie lub świadczącym usługi, rozumiemy osobę fizyczną prowadzącą działalność gospodarczą, będącą przedsiębiorcą w ujęciu ustawy z 6.03.2018 r. - Prawo przedsiębiorców (Dz.U. z 2018 r., poz. 646) (dalej: PrPrz). Zgodnie z art. 3 PrPrz, działalnością gospodarczą jest zorganizowana działalność zarobkowa, wykonywana we własnym imieniu i w sposób ciągły. Samozatrudnienie oznacza zaś świadczenie pracy na rzecz jednego lub kilku podmiotów zamawiających przez osoby fizyczne prowadzące na własną odpowiedzialność i ryzyko działalność gospodarczą w charakterze przedsiębiorcy, bez zatrudniania pracowników lub korzystania z cudzej pracy na podstawie umów cywilnoprawnych (Duraj 2007, 26). Biorąc powyższe pod uwagę, można dojść do wniosku, że każdy samozatrudniony jest przedsiębiorcą, lecz nie każdy przedsiębiorca jest samozatrudnionym. To stwierdzenie 
jest bardzo istotne z punktu widzenia przyznania ochrony prawnej w zakresie prawa do wypoczynku osobom świadczącym usługi w ramach pracy na własny rachunek.

Wprowadzenie ochrony prawnej w przedmiocie realizacji prawa do wypoczynku powinno posiadać właściwe uzasadnienie, bowiem nader często zdarza się, że ustawodawca - ustanawiając pewne uprawnienia dla poszczególnych podmiotów - nie stwarza odpowiednich kryteriów, według których stosuje się te prerogatywy. Taka sytuacja może powodować - szczególnie wtedy, gdy chodzi o przedsiębiorców - nadmierną ingerencję w zasadę wolności gospodarczej i zasadę swobody umów, co ma negatywny wpływ na realizację zamierzonego ratio legis. W moim przekonaniu, nie wszyscy samozatrudnieni powinni korzystać z prawa do wypoczynku. Dlatego też, w pierwszej kolejności, należy określić kryteria, według których nastąpi dyferencjacja w zakresie przyznania ochrony prawnej dotyczącej realizacji prawa do wypoczynku osobom samozatrudnionym. Te kryteria, które wskażę poniżej, stanowią postulaty de lege ferenda pod adresem naszego ustawodawcy.

Pierwsze kryterium powinno opierać się na ustaleniu, czy mamy do czynienia z osobą fizyczną czy prawną. Po pierwsze, samozatrudnienie może dotyczyć wyłącznie osoby fizycznej, ponieważ dla osób prawnych z przyczyn terminologicznych nie należy stosować terminu „zatrudnienie” (Skąpski 2010, 86). Po drugie zaś, nie ma wątpliwości co do tego, iż prawo do wypoczynku jest uprawnieniem konstytucyjnym, skierowanym do osoby fizycznej, czyli człowieka, a nie do osoby prawnej. W związku z tym należy stwierdzić, iż prawo do wypoczynku powinno dotyczyć wyłącznie osoby fizycznej, w tym przypadku osoby fizycznej prowadzącej na własny rachunek działalność gospodarczą.

Drugim kryterium, które należy wziąć pod uwagę przy tworzeniu regulacji ochronnej w zakresie prawa do wypoczynku dla osób samozatrudnionych, jest osobiste świadczenie usług przez pracującego na własny rachunek. Cecha ta przejawia się w tym, iż samozatrudniony - do świadczonej przez siebie pracy - nie zatrudnia innych osób zarówno na podstawie stosunku pracy, jak i stosunku cywilnoprawnego. Warto zwrócić uwagę na to, że osoba fizyczna, która zatrudnia przynajmniej jednego pracownika, staje się pracodawcą w rozumieniu art. 3 k.p. Należy dodać, że także GUS do grona osób samozatrudnionych zalicza osoby fizyczne prowadzące samodzielną działalność gospodarczą, które nie zatrudniają pracowników (Boruta 2005, 10). W moim przekonaniu, przedsiębiorca, który zatrudnia pracowników (przynajmniej jednego) lub korzysta z cudzej pracy na podstawie umów cywilnoprawnych, nie może być beneficjentem konstytucyjnego prawa do wypoczynku, ponieważ w całości nie świadczy swojej pracy osobiście, co jest istotne z punktu widzenia zasadności przyznania ochrony w omawianym przedmiocie. Jedynym wyjątkiem w tym zakresie może być korzystanie przez samozatrudnionego z pomocy członków najbliższej rodziny. Kryterium polegające na osobistym świadczeniu pracy przez pracującego na własny rachunek jest 
bardzo ważne z punktu widzenia przyznania mu ochrony prawnej w zakresie prawa do wypoczynku, ponieważ poprzez tę cechę można stwierdzić, iż samozatrudniony świadczy pracę w warunkach podobnych jak pracownik, co może uzasadniać taką gwarancję.

Kolejnym kryterium uzasadniającym wprowadzenie prawa do wypoczynku dla osób pracujących na własny rachunek jest pozostawanie w zależności ekonomicznej od swojego kontrahenta. Przez zależność ekonomiczną rozumie się taką sytuację, w której całość bądź zasadnicza część dochodów danej osoby pochodzi z jednego źródła. Polski ustawodawca niestety nie uwzględnia tego kryterium, jednak w niektórych krajach europejskich, takich jak: Hiszpania, Niemcy czy Włochy - samozatrudnienie zależne stanowi odrębną kategorię prawną ${ }^{1}$. Ustawodawca hiszpański, w specjalnej ustawie dotyczącej statusu osób samozatrudnionych, przyjął, iż do grupy samozatrudnionych ekonomicznie zależnych można zakwalifikować takiego pracującego na własny rachunek, który od jednego kontrahenta osiąga co najmniej 75\% swoich dochodów (art. 11 ustawy z dnia 11 lipca 2007 r. dotyczącej statusu pracy niezależnej - Ley 20/2007, de 11 de julio, del Estatuto del trabajo autónomo, BOE núm. 166, de 12/07/2007). Podobna sytuacja występuje w prawie niemieckim, gdzie ten próg dochodowy wynosi co najmniej $50 \%$ osiąganych dochodów (Opinion of the European Economic and Social Committee on New trends in self-employed work: The specific case of economically dependent self-employed work of 29 April 2010, SOC/344- CESE 639/2010, s. 7-8). Z kolei ustawodawca włoski, gdy chodzi o wykazanie zależności ekonomicznej, nie posługuje się progiem dochodowym, lecz tzw. kryterium stałej współpracy (Morante 2018) ${ }^{2}$. Warto dodać, że w wyżej wymienionych krajach, w których mamy do czynienia z samozatrudnieniem jako odrębną kategorią prawną, osoby pracujące na własny rachunek mają zagwarantowane prawo do wypoczynku. Ustalenie, czy pracujący na własny rachunek pozostaje w zależności ekonomicznej, jest bardzo istotne z punktu widzenia przyznania mu ochrony prawnej w tym zakresie. Występowanie takiej zależności może wskazywać na świadczenie przez samozatrudnionego pracy $\mathrm{w}$ warunkach zbliżonych do warunków pracy pracownika, co uzasadnia zagwarantowanie mu nie tylko prawa do bezpiecznych i higienicznych warunków pracy, ale także prawa do wypoczynku. Tak jak wyżej wskazałem, w Polsce samozatrudnienie zależne nie stanowi odrębnej kategorii prawnej. Należałoby zatem przyjąć konkretne rozwiązania prawne, które uregulowałaby tę kwestię. W moim przekonaniu, w tej materii trzeba oprzeć się na regulacji hiszpańskiej, która wskazuje, iż samozatrudniony zależny to osoba, która 75\% swoich dochodów osiąga od jednego kontrahenta oraz świadczy pracę o regularnym charakterze.

${ }^{1}$ Warto zwrócić uwagę, że Projekt Indywidualnego Kodeksu Pracy z dnia 29 marca 2018 r. opracowany przez Komisję Kodyfikacyjną Prawa Pracy zakłada wprowadzenie odrębnej kategorii „samozatrudnionych ekonomicznie zależnych” (art. 177-186 Projektu).

${ }^{2}$ Także w Hiszpanii jest mowa o kryterium działalności o regularnym charakterze. 
Wreszcie, ostatnim kryterium, jakie należałoby wziąć pod uwagę przy tworzeniu regulacji ochronnej w zakresie prawa do wypoczynku osób samozatrudnionych, jest okres trwania kontraktu z kontrahentem. To kryterium pozwala na odróżnienie sytuacji, w której samozatrudniony krótkotrwale świadczy swoje usługi - na przykład realizując konkretny projekt, od regularnego wykonywania pracy (usług) na rzecz podmiotu zamawiającego. Stała, permanentna współpraca pomiędzy osobą samozatrudnioną a jej kontrahentem (podmiotem zatrudniającym) powoduje, iż tworzy się pewna więź relacyjno-organizacyjna. Warto dodać, że te powiązania nie występują tylko pomiędzy tymi dwoma podmiotami, ale także pomiędzy samozatrudnionym a pracownikami podmiotu zatrudniającego. Kryterium stałej współpracy jest bardzo istotne z punktu widzenia przyznania ochrony w zakresie wypoczynku osobom samozatrudnionym (spełniającym powyższe kryteria), ponieważ w tym przypadku mamy do czynienia z podmiotem, który - podobnie jak pracownik - świadczy pracę o trwałym charakterze. W moim przekonaniu, aby uznać, iż współpraca ma taki właśnie charakter, należy konkretnie określić, jaki czas powinno trwać świadczenie pracy na rzecz podmiotu zatrudniającego. Według mnie, należy tu przyjąć nieprzerwany sześciomiesięczny okres współpracy, ponieważ jest to czas wystarczający do tego, aby strony umowy wzajemnie się poznały i podjęły decyzję o dalszym współdziałaniu.

\section{PODSUMOWANIE}

Konstytucyjne prawo do wypoczynku winno przysługiwać nie tylko pracownikowi, ale również każdej osobie (w tym samozatrudnionemu), która wykonuje pracę $\mathrm{w}$ warunkach zbliżonych do stosunku pracy, bez względu na więź prawną łączącą ją z podmiotem zatrudniającym. Zakres podmiotowy prawa do wypoczynku nie powinien być jednak rozciągnięty na wszystkie osoby fizyczne prowadzące działalność gospodarczą, lecz tylko na te podmioty, które są organizacyjnie i ekonomicznie zależne od swojego kontrahenta. Dlatego też, gwarantując poszczególnym jednostkom dodatkowe prawa i obowiązki, zwłaszcza te, które mogą ingerować w wolność gospodarczą oraz zasadę swobody umów, należy określić szczegółowe kryteria, według których będą one przyznawane. Jest to bardzo istotne, ponieważ prawo powinno chronić jedynie te podmioty, które rzeczywiście tego potrzebują. W związku z tym - tworząc regulację ochronną w zakresie prawa do wypoczynku dla osób samozatrudnionych - należy wziąć pod uwagę sytuację faktyczną osoby, która w ramach prowadzonej przez siebie działalności gospodarczej świadczy regularną pracę na rzecz podmiotu zamawiającego. W związku z tym, że ta problematyka wywołuje wiele kontrowersji i jest niejednoznaczna, należałoby dokonać rewizji przepisów konstytucyjnych i rozszerzyć zakres podmiotowy w art. 66 ust. 2 Konstytucji RP na każdego człowieka. 


\section{BIBLIOGRAFIA}

Banaszak, Bogusław. 2009. Konstytucja Rzeczypospolitej Polskiej. Komentarz. Warszawa: Wydawnictwo C.H. Beck.

Banaszak, Bogusław, Mariusz Jabłoński. 1998. „Komentarz do art. 66”. W Konstytucje Rzeczypospolitej oraz komentarz do Konstytucji RP z 1997 r. Red. Jan Boć. Wrocław: Wydawnictwo C.H. Beck.

Boruta, Irena. 2005. „W sprawie przyszłości prawa pracy”. Praca i Zabezpieczenie Społeczne 4: $3-12$.

Daniluk, Paweł, Wioletta Witoszko. 2006. Glosa do uchwaty SN z dnia 15 grudnia 2005 r., I KZP 34/05, OSP 7-8, poz. 93.

Dral, Antoni, Beata Bury. 2014. „Zasada ochrony pracy w Konstytucji RP”. Przeglad Prawa Konstytucyjnego 3: 231-251.

Duraj, Tomasz. 2007. „Prawna perspektywa pracy na własny rachunek”. W Praca na własny rachunek - determinanty i implikacje. Red. Elżbieta Kryńska. Warszawa: Wydawnictwo IPiSS.

Garlicki, Leszek, Marek Zubik. 2016. Konstytucja Rzeczypospolitej Polskiej. Komentarz. Tom II, wyd. II. Wydawnictwo Sejmowe.

Jankowiak, Jarosław, Anna Musiała. 2007. „Glosa do uchwały SN z dnia 15 grudnia 2005 r. I KZP 34/05". Prokuratura i Prawo 2: 163-167.

Lewandowski, Tomasz. 2009. „Prawo człowieka do bezpiecznych i higienicznych warunków pracy". Wiedza Prawnicza 3: 16.

Liszcz, Teresa. 2009. „Prawna ochrona niepracowniczego zatrudnienia na podstawie umowy według Kodeksu pracy”. W Jedność w różnorodności. Studia z zakresu prawa pracy, zabezpieczenia społecznego i polityki społecznej. Ksiega pamiątkowa dedykowana Profesorowi Wojciechowi Muszalskiemu. Red. Andrzej Patulski, Krzysztof Walczak. 177-188. Warszawa: Wydawnictwo C.H. Beck.

Sanetra, Walerian. 1997. „Prawa (wolności) pracownicze w Konstytucji”. Praca i Zabezpieczenie Społeczne 11.

Skąpski, Michał. 2010. „Problem pojęcia i prawnej regulacji samozatrudnienia”. W Stosunki zatrudnienia $w$ dwudziestoleciu spotecznej gospodarki rynkowej. Ksiega pamiatkowa z okazji jubileuszu 40-lecia pracy naukowej Barbary Wagner. Red. Arkadiusz Sobczyk. 85-96. Warszawa: Wydawnictwo Wolters Kluwer.

Sobczyk, Arkadiusz. 2013. Prawo pracy w świetle Konstytucji RP. Teoria publicznego i prywatnego indywidualnego prawa pracy. Warszawa: Wydawnictwo C.H. Beck.

Szanciło, Tomasz. 2005. „Przedsiębiorca w prawie polskim”. Przegląd Prawa Handlowego 3: 4-12.

Świątkowski, Andrzej Marian. 2016. „Konstytucyjna koncepcja pracownika”. Monitor Prawa Pracy 1: 8-15.

Wiącek-Burmańczuk, Aleksandra. 2017. „Konstytucyjne prawo do wypoczynku”. Przegląd Sejmowy 5(142): 109-123.

\section{Strony internetowe}

http://www.mop.pl/doc/html/konwencje/k001.html [dostęp 3.09.2019]

http://www.mop.pl/doc/html/konwencje/k030.html [dostęp 3.09.2019]

http://www.mop.pl/doc/html/konwencje/k047.html [dostęp 3.09.2019]

$\mathrm{http}: / /$ www.mop.pl/doc/html/konwencje/k106.html [dostęp 3.09.2019] 


\title{
Mateusz Barwaśny
}

\section{RIGHT TO REST OF THE SELF-EMPLOYED - DE LEGE FERENDA COMMENTS}

\begin{abstract}
The subject of this study is the issue related to the right to rest of the self-employed. The current provisions of the Constitution of the Republic of Poland of 2 April 1997 in this matter are not unambiguous and they should be reviewed. First of all, they are not in compliance with acts of international law. Secondly, they do not reflect the current socio-economic realities. In the author's opinion, the subjective scope of the right to rest should be extended to the self-employed who meet the criteria set out in the study.
\end{abstract}

Keywords: self-employment, the right to rest. 